\title{
Bankruptcy Proceedings for Sovereign State Insolvency and their Effect on Capital Flows
}

\author{
Jonathan P. Thomas *
}

October 2003

\begin{abstract}
The paper examines the main issues involved in translating domestic bankruptcy procedures to the sovereign context. It considers some of the principles by which domestic bankruptcy procedures operate, and the extent to which they apply to international lending. Two recent proposals are considered in more detail, that of Krueger ('A New Approach to Sovereign Debt Restructuring') and that of Pettifor ('Resolving International Debt Crises - The Jubilee Framework for International Insolvency'). The paper also considers the question of the ex ante effects of a procedure which makes default less costly, and concludes that despite a negative impact on the ability to borrow, the overall welfare effect need not be negative.
\end{abstract}

Keywords: sovereign debt, bankruptcy, capital flows, Chapter 11

JEL classification: F34

* University of Edinburgh

This study has been prepared within the UNU-WIDER project on the Sustainability of External Development Financing, which is directed by Matthew Odedokun.

UNU-WIDER gratefully acknowledges the financial contributions to the 2002-2003 research programme by the governments of Denmark (Royal Ministry of Foreign Affairs), Finland (Ministry for Foreign Affairs), Norway (Royal Ministry of Foreign Affairs), Sweden (Swedish International Development Cooperation Agency - Sida) and the United Kingdom (Department for International Development). 


\section{Acknowledgements}

Paper prepared for the UNU-WIDER Project Meeting: 'Sustainability of External Development Financing'. I am grateful for support from UNU-WIDER and also for comments made by Matthew Odedokun, Mansoob Murshed, Leonce Ndikumana, Tony Addison, Robert Lensink and other project participants. I am also grateful for support from the ESRC project R000239216 'Moral Hazard and Financial Institutions'. A non technical version of this paper entitled 'Bankruptcy Proceedings for Sovereign State Insolvency' is forthcoming in the World Economy.

The World Institute for Development Economics Research (WIDER) was established by the United Nations University (UNU) as its first research and training centre and started work in Helsinki, Finland in 1985. The Institute undertakes applied research and policy analysis on structural changes affecting the developing and transitional economies, provides a forum for the advocacy of policies leading to robust, equitable and environmentally sustainable growth, and promotes capacity strengthening and training in the field of economic and social policy making. Work is carried out by staff researchers and visiting scholars in Helsinki and through networks of collaborating scholars and institutions around the world.

www.wider.unu.edu publications@wider.unu.edu

UNU World Institute for Development Economics Research (UNU-WIDER)

Katajanokanlaituri 6 B, 00160 Helsinki, Finland

Camera-ready typescript prepared by Liisa Roponen at UNU-WIDER

Printed at UNU-WIDER, Helsinki

The views expressed in this publication are those of the author(s). Publication does not imply endorsement by the Institute or the United Nations University, nor by the programme/project sponsors, of any of the views expressed. 


\section{Introduction}

The recent proposal by Anne Krueger (2001) of a 'sovereign debt restructuring mechanism', or SDRM for short, has sparked a wide ranging debate amongst academics and practitioners concerning the merits or otherwise of formal legal structures for dealing with distressed debtors. According to Krueger, 'the objective of an SDRM is to facilitate the orderly, predictable, and rapid restructuring of unsustainable sovereign debt, while protecting assets values and creditor's rights'. It is argued that the shift from syndicated bank loans to bond finance that has taken place over the last 20 or so years has created a number of coordination problems when the sovereign country finds itself in payments difficulties. Not only are typical bond holders less involved in the economies concerned than were banks, but their diffusion means that it is very difficult for bond holders as a group to agree to any restructuring of debts. Free rider problems, it is argued, are much worse than they were perceived to be in the 1980s, as single bond holders can 'hold out' in the hope of obtaining payment according to their original contract, or the hope of being bought out by other creditors, while the mass of creditors agree to a reduction in their claims on the sovereign.

Recent experience strongly suggests that sovereign debt crises remain a major policy concern. There have been outright defaults on external debt in Ecuador, Argentina and Russia. Countries such as Ukraine, Pakistan, Korea, Thailand, and Indonesia have avoided outright default but have had to impose some kind of standstill, debt exchange or rollover. Others have been bailed out (Turkey, Mexico in 1995) or have renegotiated (Brazil in 1999). The Asian crisis, while not initially a classical sovereign debt problem, developed into one as public sectors guaranteed private sector external debts. The current Argentinean crisis is being closely monitored. Despite apparently doing most of the 'right things' throughout the 1990s, by 1998/9 matters were going wrong, with a financing requirement of around \$20bn a year needed in the face of a sceptical capital market. This led to a large bailout at the end of 2000 of $\$ 40 \mathrm{bn}$ (\$14bn of which came from the IMF), with more to follow shortly afterwards, and another large disbursement of money from the IMF in September. By the end of 2001, however, there was a run on the banks, leading to their eventual closure, and the end of the Convertibility Plan, and default on its external debt. The difficulties facing any successful restructuring include the size of the restructuring needed, the existence of a range of differing instruments, a very diverse creditor base, and the importance of domestic debt. Many commentators are watching to see if a successful restructuring can be achieved without recourse to a statutory mechanism of the sort discussed here. If so, then the arguments for a wholesale change of the system will be less compelling.

The paper gives a brief overview of the principal issues involved in translating domestic bankruptcy procedures to the sovereign context, and summarizes some recent specific proposals, including the SDRM. The paper will also consider in some depth whether a formal bankruptcy procedure would so reduce the costs of default that default rates would rise and in response lenders would restrict lending and/or increase risk premia. Some commentators argue that this would lead to a reduction in future capital flows to developing countries that would ultimately be to the detriment of debtor country welfare.

Due to space limitations, we shall not discuss other than in passing the question of whether a less ambitious 'contractual' approach which would encourage the inclusion of collective action clauses in bond contracts, as put forward by John B. Taylor of the US 
Treasury (Taylor 2002), amongst others, might offer a more realistic approach to solving many of the problems associated with sovereign debt crises. Suffice it to say that countries already have the option of issuing debt under UK law, which allows such clauses to be included, including majority voting to prevent litigation by holders of a particular bond issue, and if this option is not being exclusively used then one imagines that there must be some reason for that. ${ }^{1}$ To bring such an approach about, a degree of coercion may be necessary. ${ }^{2}$

\section{The analogy between domestic bankruptcy procedures and sovereign debt restructuring}

\subsection{Motivation}

According to Eichengreen and Portes (1995), there are two main features of an efficient bankruptcy court. The first is that it should maximize the ex post value of the firm, while the second is that it should ensure that the bonding role of debt is preserved. The latter means that the bankruptcy procedure should not create incentives for debtors to resort to bankruptcy.

It is not clear that the logic behind either of these features carries over to the sovereign debt context. 3 Maximizing the ex post value of the firm may be interpreted in the sovereign debt context as a restructuring (and possible commitment by the country to an economic adjustment programme), in order to maximize the value of repayments to the creditors. To be sure, such a restructuring may also be in the interests of the country. But there is no compelling reason why the interests of the debtor country should not be given a higher priority. Likewise, making the bankruptcy process sufficiently painful for the debtor country, in order to preserve the bonding role of debt, is not obviously ex ante very efficient. Even in the simplest model, with a risk averse country one would like debt repayments to take into account the circumstances of the country. 4 Preserving the bonding role of debt works against this. A very harsh bankruptcy regime (or the absence of a bankruptcy regime at all) may preserve the bonding role of debt, but it also may mean that countries which fall on bad times suffer unduly. It may actually be ex ante efficient to cut the costs or shift the terms or any bankruptcy regime in favour of

1 The Rey Report (Group of Ten 1996) recommended their use, but this does not appear to have had much impact on their implemtation. However Mexico has recently incorporated a clause into its New York law bonds.

2 A number of commentators have dismissed the plan almost out of hand; e.g., 'The US plan has superficial attractions but is unworkable' (The Financial Times, leader, 4 April 2002: 24). Others see it as the right approach, but also take the view that the development of the Krueger proposal may act as an incentive for adoption of the clauses in loan contracts (see Miller 2002). Eichengreen (2002) argues that a 'Krueger-like' statutory process is probably required to implement this approach.

3 Eichengreen and Portes had in mind corporate bankruptcy and analogies between Chapter 11 of the US code, and a bankruptcy court for sovereign debtors (although they came out broadly in favour of a contractual approach). The motivation for personal bankruptcy law, and that for municipalities, is different; see the discussion below.

4 There have been attempts to introduce financial instruments contingent on relevant economic variables, such as commodity bonds, but these have not proven successful. Likewise the International Finance Corporation attempted unsuccessfully to create a market in put options to enable investors to limit their downside risk. 
the debtor country, to allow the country more insurance. The downside of this, however, would be that lenders would be less willing to lend. So there will be a trade-off. 5

Likewise, countries may be subject to 'debt traps' and extracting large repayments from them may imply that they remain stuck in the trap6 (see Sachs 2002). Even if such a country were risk-neutral, it may be efficient to extract less repayment in states of the world where the country may be in danger of getting trapped at a low level, so that this can be prevented.

While one might then argue that the fundamental motivation for corporate bankruptcy law is partially at odds with what is needed in the sovereign debt context, there is no doubt that similar collective action problems arise in both cases, and it is surely here that the analogy is most useful. The first collective action problem can arise before a standstill on payments or de facto default occurs, namely a creditor grab race. This has two elements. First, there may be a rush to the exits by creditors which can diminish the value of the assets of the debtor in the corporate case, and in the sovereign debtor case, can lead to severe economic dislocation. A rush to the exits in the corporate context may lead to inefficiency because an otherwise profitable concern is closed down, and it can be argued that a similar scenario can arise in the sovereign debt context. In the latter, commentators have tended draw comparison also with bank runs. For example, Eaton (2002) uses a variant on the Diamond and Dybvig (1983) model, to show how if one creditor fails to renew its loan, then all creditors will do likewise. A very similar problem can arise over a failure to extend new financing (or roll over short-term loans), either to a corporate body, or indeed to a country. The (same) collective action story implies that creditors as a group may fail to extend new finance, even though it may be in their collective interest to do so. Second, a rush to the court house can ensue, with each creditor attempting to be the first to attach a claim to any assets.

The second area where the collective action problem is seen to raise its head, is in bargaining over restructuring. Here, problems include rogue creditors (such as the much cited case of Elliott Associates in the recent Peruvian Restructuring) who are prepared to sue in the courts for full payment. At a less extreme level, in multi-party bargaining, there is a problem of 'hold outs' who will not settle, even though the majority of creditors would agree to a package. A motivation for this behaviour may be the hope of being bought out by the other creditors, eager to resolve the negotiations, as indeed happens in practice. Asymmetric information about the future prospects of the country is also likely to lead to delays in bargaining (and can also rationalize why different parties will be prepared to settle at differing terms).

In both of these areas, bankruptcy legislation can resolve such collective action problems. A payments standstill and stay on litigation can prevent a creditor grab race, and the agreement of a restructuring plan under (super)majority voting can overcome the problem of hold outs. It should be noted that these are to preserve creditor value. Thus, for example, the stay on litigation is to protect creditors from the behaviour of

5 In Section 5, I develop a simple model to examine this trade-off.

6 There are a number of reasons given for the existence of a debt trap. It may, for example, be that there is some threshold level of domestic saving below which output is very low due to nonconvexities in production functions. Alternatively, the savings rate itself might fall towards zero at low levels of income. 
other creditors. It is not entirely clear that they would work the same way in the sovereign context. A payments standstill, by 'bailing in' the private sector, might be to creditors' disadvantage, particularly if the alternative is an IMF 'bail out' (see below). Stays on litigation and majority voting may weaken the overall bargaining position of creditors. 7

However the view that collective action problems are severe and in need of being addressed by a formal mechanism has its critics. Roubini (2002) for example argues that collective action problems are not as severe in the sovereign debt as in the corporate context. He cites examples where dispersion and heterogeneity of creditors have not hindered restructuring: Pakistan, Ukraine, Russia, Ecuador have all succeeded with unilateral exchange offers (with close to 100 per cent of creditors accepting the offers). He also takes the point of view that the rogue creditor problem has been exaggerated. The judgement in favour of Elliott Associates in the case of Peru (allowing the blocking of payments to creditors that have accepted an exchange offer) is highly unusual and unlikely to be repeated.

A rather different motivation for bankruptcy law is that it should provide a 'fresh start' to an insolvent debtor (e.g., Sachs 2002). This is not the primary motivation in corporate bankruptcy procedures, but is found in procedures for personal and municipal bankruptcy. In the case of personal bankruptcy, this is grounded in the autonomy of an individual, so that the debtor is essentially freed from future claims by the creditors. It should be noted that this aspect of bankruptcy procedure has nothing to do with collective action problems.

Finally, one motivation exists for a bankruptcy procedure in the sovereign debt realm which is normally, but not always, absent in the corporate or civic spheres, concerning the possibility of public sector bail-outs and the so-called moral hazard problem. The moral hazard problem in international lending is generally seen to be due to the problem that private lenders will lend too much, relative to the capacity of borrowers to repay, anticipating that if a problem should occur, the international community will provide bail-out funds. This idea partly appeals to the (very controversial) idea that the debt of the IMF and other International Financial Institutions (IFIs) is effectively junior to that of private creditors, contrary to the usual doctrine. The idea is that the private creditors will benefit from the bail-out, or in other words, that the IFIs will effectively subsidize the private creditors. Alternatively, if IFI debt truly is senior, so that IFIs do not provide a subsidy, the bail out may still allow creditors to exit at a low cost, but leave the burden of repaying the bail-out on the debtor. This will still affect ex ante incentives if it is perceived that the debtor is more likely to pick up the tab in an adverse event. Assuming then that this moral hazard problem is important, a payments standstill, by freeing the IMF from the trap of having to bail out the country, may force creditors to realize that it is in their own interest to roll over the debt (i.e., force a 'bail in'). It is argued that elimination of the moral hazard problem will lead to more appropriate levels of spending. This has been argued, for example, by Miller and Zhang (2000). The whole question of moral hazard created by bail outs, and the need for 'private sector involvement,' remains controversial and will not be addressed in detail here.

7 It is argued that during the 1930s defaults, majority voting allowed settlements to take place on terms favourable to the debtor countries, with private minority creditors being forced to accept these terms. This is the reason why US law subsequently denied the possibility of collective action clauses in bonds (see Eichengreen and Mody 2000). 


\subsection{Bankruptcy models}

We turn next to a very brief survey some relevant aspects of different models for bankruptcy, largely based on US law, which have received much attention in the recent debate (I will concentrate mainly on features which share some similarity with issues arising in a sovereign debt context).

Chapter 11 is the bankruptcy procedure most commonly appealed to in connection with sovereign debt bankruptcy proposals. Chapter 11 is the procedure for corporations, and in contrast to liquidation (Chapter 7), it allows companies to continue operating, the idea being that the value of future profits may be greater than the current liquidation value. Existing managers usually, but not always, remain in control of the company. Critical features of Chapter 11 are, firstly, an automatic stay which stops litigation against the company for the period of the stay. Second, interest on unsecured debt is not paid until the reorganization plan is settled. Thirdly, new loans take priority over all prebankruptcy claims, and hence this makes obtaining new finance much easier. (This is referred to as a 'debtor-in-possession financing'; if new finance were to be treated on a par with existing claims, it is highly unlikely that any new funding would be available since prospects for repayment would be so unfavourable.) A reorganization plan is adopted by a voting procedure: all classes of creditors and equity (as a single class) need to approve the plan, and by a super majority in amount (two-thirds). Critical in this process, is what would happen in the absence of a plan being agreed. The firm may be liquidated, in which case creditors are repaid according to the absolute priority rule so that the administrative expenses of bankruptcy are paid first, other claims such as taxes and outstanding wage come next, then unsecured creditors (possibly not equally if there are subordination agreements), and finally equity, if anything is left. (Secured creditors are outside of the priority rule, and may receive payment even when no other creditor does.) Alternatively, the judge may adopt the reorganization plan using a procedure known as 'cramdown'. This requires a 'best interest of creditors' test to be satisfied, but again the fall back position against which this is measured is essentially what creditors would receive if the firm were to be liquidated.

Of course, attempting to use Chapter 11 as a basis for a sovereign insolvency procedure will be limited by the substantial contrasts between corporate debt and sovereign debt. Sovereign debt is, with few exceptions, not collateralized. This is also true of unsecured corporate debt. The difference is, however, that the latter still has a claim on the assets of the company in the event of bankruptcy, and must be repaid before equity receives any payment. Moreover, in contrast to corporate debt, sovereign debt has equal priority (with the principal exception of IMF and World Bank debt). Another major difference is that corporate bankruptcy implies that management may lose control. Under Chapter 11 legislation, unless the management can come up with an appropriate reorganization plan, it risks being replaced, or at least having an alternative plan imposed upon it. This consideration is important for the incentives facing managers in the bankruptcy decision. (Chapter 11 is favourable to management by international comparison; under UK bankruptcy law, for example, replacement of incumbent management is more immediate; see below.) Of course sovereign default can trigger a political crisis in which the incumbent government is replaced, so the incentives facing corporate management and country governments may not be so dissimilar after all.

Chapter 9 provides protection for public bodies 'insolvent or unable to meet its debts as they mature' (a more stringent test than that used in Chapter 11), and which have failed 
to work out a solution with creditors. Only the municipality can file (with the authorization of the state). Once a municipality files under Chapter 9, the court issues a stay against litigation by creditors. A crucial distinction between Chapters 9 and 11 of the US code, is that the former protects the governmental powers of the debtor and also individuals who are affected by any reorganization plan-public officials cannot be replaced, unlike corporate management. Another distinction is that only the public officials can offer a restructuring plan (or the judge). The court must be satisfied that any plan of adjustment is fair, equitable, and feasible, and also must be in the interests of the creditor. Being in the interest of the creditor means that they should get what they would reasonably expect in the prevailing circumstances. Adoption of a plan requires similar super majorities in voting as under Chapter 11.

According to White (2002), what happens if a plan is not adopted by vote is ambiguous (an observation she also makes about the Krueger proposal). The main point here is that under Chapter 11 legislation, the 'fall back' position is effectively that of liquidation (i.e., Chapter 7). This acts as the reference point in negotiations, and also in the cramdown procedure. In Chapter 9, however, this possibility does not exist, although there is a theoretical possibility (never used) for the bankruptcy judges to impose their own plan on the municipality. She also points out that Chapter 9 has only rarely been used, and consequently the law is underdeveloped.

In general, the important distinction that reformers would draw between Chapter 11 and Chapter 9, is that in the latter the municipality's provision of services to its citizens should not be unduly compromised. That is to say, the municipality can continue to make basic choices without interference by the creditors or the court. In addition stakeholders have the opportunity to voice their approval or disapproval of the debt reorganization plan. Both of these features, it is argued, should be linchpins of a sovereign bankruptcy procedure.

Finally, it should be added that there is another possible model for a bankruptcy court for sovereign debtors, namely one based on personal bankruptcy. In individual bankruptcy (Chapter 7 or Chapter 13) creditors do not obtain the maximum value feasible from the debtor, similar to Chapter 9 for municipalities. Under liquidation (Chapter 7), for example, creditors are paid out of the property of the bankrupt estate, and even then certain assets are exempt, such as a home up to a certain value. Crucially, remaining debts are then discharged, so that households are not required to devote future income to debt repayment. Debtors can also choose to file under Chapter 13, where they are not obliged to give up any assets, but must put together a plan in order to repay (at least a portion of) their debts over time. The relevance of personal bankruptcy law for the sovereign case, and particularly the idea of a 'fresh start', has been emphasized by Sachs (2002); see Section 1. Moreover developing country debt bears a close resemblance to consumer debt (Bulow 2002). First, default occurs in both cases when the amount of debt is relatively low in comparison to income-typically equal to only a few months' income. Second, in both cases, there is an expectation that default is likely, and this is reflected in interest rates which are high.

While the above discussion, and indeed most of the recent debate, has been conducted with reference to the US Code, it should be noted that bankruptcy procedures differ markedly between countries. In terms of corporate bankruptcy, for example, Chapter 11 of the US Code is thought to be debtor (management) oriented, in order to maintain the business as a going concern, even at the expense of the creditors. The board of the 
company has substantial rights to retain control of the business while a reorganization plan is being put together. In contrast, the UK Code, for example, prioritises the repayment of creditors' claims. Under the UK code, there are various possibilities but they have in common the transfer of control to an insolvency practitioner who represents the interests of creditors. It is more difficult to draw lessons from the UK Code for international bankruptcy procedures for the very reason that transfer of control is problematical in the sovereign context (see the discussion above).

\subsection{Recent proposals}

In this section we outline two proposals that have recently been made to introduce more formal bankruptcy procedures into the sovereign debt context. 8 These are the respective proposals made by Anne Krueger, deputy managing director of the IMF, and Anne Pettifor for the Jubilee Coalition.

Krueger outlines two key challenges that an SDRM should address. The first is that it should encourage debtors to behave 'in a manner that preserves asset values and paves the way toward a restoration of sustainability and growth'. The second is that, once the SDRM is triggered, there should exist incentives 'for all parties to reach rapid agreement on restructuring terms that are consistent with a return to sustainability and growth'.

Krueger (2002) identifies the following core features that could be included in what she terms a sovereign debt restructuring mechanism (SDRM). The mechanism is intended for use only when the debt burden is clearly unsustainable. Consequently, it is relevant only in situations where a significant reduction in the sovereign borrower's debt is required, and it is not relevant in situations where a temporary liquidity problem arises, requiring no more than a rescheduling of obligations. First, the process would exhibit majority restructuring. This would imply that a qualified majority of creditors could assent to a restructuring agreement, despite the objections of any dissenting minority. This would deal with the problem of hold outs in the restructuring process. Second there would be a stay on creditor enforcement. If an agreement had not been reached prior to a default, a temporary stay could be granted on creditor litigation after a suspension of payments but before a restructuring agreement is reached. This would prevent a grab race from developing. As Krueger points out, the incorporation of qualified majority restructuring, as just described, might very well increase the risk of a grab race ensuing since creditors will have less leverage once an agreement is reached. The next important feature she lists is protecting creditor interests. To reassure creditors that their interests are being protected during a period of a stay, the debtor would be required 'not to make payments to non-priority creditors'. Moreover, some guarantee that the country was following responsible economic policies would probably be required. For example, the country might be implementing an IMF programme, or at least it may have to obtain support from the IMF that it is behaving in an appropriate manner. Finally, there is priority financing. An SDRM could facilitate the provision by creditors of new financing by making such financing senior to all pre-existing debts. This is analogous to a 'debtor in possession financing' envisaged under Chapter 11 of the US bankruptcy

8 The idea of a bankruptcy court for sovereign debtors is not new. In fact it goes back to Adam Smith. See Rogoff and Zettelmeyer (2002) for a history of the idea. The paper by Sachs (1995) partly reignited the debate. 
code. Without such priority, creditors have little incentive to provide new finance, even if it is in their interests collectively to do so.

The idea of an SDRM is aimed at commercial debt in middle income countries. It is not meant for the very low income countries, the argument being that they are already being dealt with under the HIPC initiative. (By contrast, the bankruptcy process envisaged by the Jubilee coalition would apply to all countries that have difficulty servicing their debt.) An important distinction between the two groups is that the vast majority of the debt owed by the very low income countries is official debt, while this is not the case for the middle income countries. Consequently, the design of the SDRM is primarily aimed at the restructuring of commercial debt. Indeed, the claims of IFIs would not be subject to the mechanism (Krueger 2002: 17), as they are treated as being senior by the international community. The issue of whether bilateral debt should be subject to the mechanism is left open. (In contrast, the Pettifor proposal would apply to all types of debt, including that owed to IFIs.) Essentially there are two options. First, if bilateral debt is excluded, then there would be a parallel, but independent, Paris Club process to determine the extent of bilateral debt restructuring. Comparability of treatment and coordination between the two processes might be problematic. Second, if official debt is included in the SDRM, then the suggestion in IMF (2002) is that it should be as a separate class, in analogy with the treatment of different classes of creditor under Chapter 11, so that each class may be treated differentially, but equally each class has a veto over the whole agreement. A drawback of this is that it would dispense with the Paris Club, a well developed procedure for dealing with official bilateral debt, with an expertise built up over many years.

One practical issue is the treatment of domestic debt. 9 Inter-creditor equity may demand that it is not just external holders of debt who agree to a reduction in claims. Should the claims of resident investors also be subject to the majority restructuring provisions of the mechanism? This is left open. A restructuring which affected asset values in the local banking sector, for example, could precipitate (or exacerbate) a banking crisis, and thus there may be strong arguments for excluding at least some elements of domestic debt. Domestic debt could be brought in, again, as a separate class (hence potentially subject to differential treatment), holding a veto over the whole process. The drawback here is that introducing too many classes of debt can bring back some of the coordination problems which the procedure was designed to overcome. 10 However, even the definition of domestic debt is fraught with difficulties. Should its definition depend on the residence status of the creditor, the currency in which the instruments are denominated, or even whether the governing law is domestic or not? In IMF (2002) the latter seems to be preferred.

Other open questions include the question of who can initiate a standstill. While initially it was assumed that IMF approval would be required, later versions toned this down, and in IMF (2002) it is assumed to be left as a unilateral decision of the sovereign. 11 The later versions also play down the role of the IMF elsewhere in the process. This is

9 Such issues need to be addressed by any formal bankruptcy mechanism.

10 Whether bilateral debt and domestic debt should be formally included in the SDRM is arguably not a vital matter given that restructuring of either is possible outside of the SDRM without the same issues arising that might affect commercial debt issued under other jurisdictions.

11 In January 2003, it was proposed a stay could be dropped altogether. 
in response to a widespread reaction that the IMF, itself a creditor and having political masters that may be influenced by other creditors, 12 may not be regarded as impartial. 13 Also, if exchange controls are imposed, should legal protection be extended to solvent firms prevented from servicing their debts?

What of the legal side? Introducing collective action clauses probably needs changes in national law requiring their use in all bond contracts. It is also generally thought that the full-blown Krueger approach would require changes to the IMF's Articles of Agreement. The idea would be that the class of contracts covered in Article VIII could be broadened to include all contracts. Then, if the IMF approved the suspension of payments on debt, the debt contract would be unenforceable in the courts of any IMF member. See also Greenwood and Mercer (1995) for discussion of other possibilities, including a separate international treaty.

Objections to the Krueger proposal include the following. It is not obvious that it identifies the problem correctly. The general move towards bond finance does not necessarily mean that restructurings have become more difficult than they were in the days of syndicated bank lending (see Roubini 2002). The possibility of precluding litigation against the debtor, even for a limited period,14 is much stronger than what would result from a contractual solution which incorporates collective action clauses. The latter does not prevent creditors from suing provided a sufficient majority is in favour. The Krueger proposal is therefore very favourable to debtors, and the possibility of opportunistic behaviour would need to be minimized. Moreover, the idea that the IMF should activate a standstill is controversial, although this has been downplayed in later versions of the proposal. Debtors may see it as diminishing their powers to act in a crisis; creditors, who are already distrustful of the motives of the IMF, will not want to see it granted extra powers. More radical critics object to the exclusion of certain types of official debt.

A rather different approach is taken by Pettifor (2002), based on the work of Kunibert Raffer who argues in favour of using Chapter 9 (rather than Chapter 11) as a model for an international insolvency court (e.g., Raffer 1990). Raffer claims that it would be relatively straightforward to implement this idea. International treaty arrangements on an ad hoc basis would be adequate. There are two main precedents for this. The first was the agreement of 1952 whereby the German government negotiated a 50 per cent debt reduction relating to its Versailles and Nazi era debts. The second precedent was a similar cut in Indonesian debt, in 1969. Ad-hoc courts with a small number of arbitrators could be appointed. In each instance, members of the court would be appointed by the parties involved.

Pettifor envisages that the process would apply to all indebted nations, hence including the HIPC countries. The bankruptcy court would be constituted as an ad hoc body, with

12 Commercial creditors were worried that the official creditors would avoid taking a 'haircut', while for debtors, having a creditor overseeing the process is unsatisfactory.

13 Interestingly, both of these aspects are part of the proposal made by Pettifor (2002), and there does appear to be some convergence between the two proposals, including a recognition by the IMF of the need for civic involvement in the consultation process.

14 Under the proposal in Krueger (2002), extension of a stay beyond 90 days should require the assent of a committee of creditors. 
appointees nominated by the debtor and creditor, with a judge agreeable to both sides. The independence of the court is fundamental. There is emphasis on a process of ascertaining whether debts were contracted legitimately.15 As in Chapter 9, parties affected can participate in the process, and this is given prominence in the proposal. Citizens will be able to have their responses heard. The guiding principle is to be justice, including the protection of fundamental human rights, in addition to the rights of creditors. The debtor should emerge from the process 'with reasonable prospects of financial stability and economic viability'. An appealing feature of this proposal is that it is in line with current international policy thinking on grassroot participation ('bottom-top approach') and ownership of economic policies.

While it shares with the Krueger proposal an automatic stay on debt payments, and recognizes the existence some of the collective action problems which Krueger emphasizes, the motivation is rather different, appealing to justice and the protection of rights. The process should allow the sovereign to escape from illegitimate loans and irresponsible behaviour on the part of both lenders and borrowers. Implicit also is that debt relief is likely to be more substantial than under the Krueger proposal where a return to debt sustainability only is suggested.

A weakness common to both proposals is that it is not fully clear what happens in the case of disagreement. In the Pettifor proposal, the court will mandate the final composition plan: 'The court would have to bind all creditors, and the debtor, to a debt reduction agreement which is "fair, equitable and feasible". It must be in the best interest of creditors - which is tested by what they could reasonably expect to be paid' (Pettifor 2002: 10,16). At various points in the Pettifor proposal, there appears to be an implication that affected citizens should have the power to block a composition plan. Moreover the United Nations is supposed to ensure that any plan preserves fundamental human rights. Under Chapter 11, because the alternative to an agreement is liquidation, a fairly clear process is identified involving voting by creditors, even in the case where there is no agreement on a proposal. Moreover, if the judge has to act, the alternatives before him or her are clear. As already mentioned, this is not the case under Chapter 9 and there has not yet been a case under Chapter 9 where the judge has had to impose an outcome. In the sovereign case, it seems even likelier that the situation would be substantially more difficult to resolve by unilateral action of the court.

A further common problem is the question of debtor moral hazard. There are two main elements. First, a debtor might take unnecessary recourse to bankruptcy if it perceives this to be in its interest. It is acknowledged that insolvency is particularly difficult to both define and verify in the sovereign debtor case, and consequently it may be difficult to discern opportunistic behaviour from genuine need. It may be that the vagueness of what happens in the case of disagreement, discussed in the previous paragraph, is useful in this regard. If there is a sense among creditors that the debtor is being opportunistic, then they are unlikely to be prepared to accept substantial debt relief. An explicitly defined procedure might, on the other hand, allow the debtor to force large concessions out of the creditors. Second, the prospect of a less costly default might induce behaviour on the part of the debtor which increases the likelihood of default.

15 This may appeal to the idea of 'odious debt' where a state may justifiably repudiate debts incurred by tyrants no longer in power (see Kremer and Jayachandran 2001). 
A criticism of the Pettifor proposal as it applies to the HIPC countries is that donors might be forced by the court to grant debt relief, but they could often simply offset this by cutting future transfers. Birdsall and Williamson (2002) argue that donors would never lock themselves into an approach that would coerce from them additional net transfers. In general, the political feasibility of the radical Pettifor proposal is open to question given the resistance that even the relatively conservative Krueger proposal is meeting.

\section{The costs and benefits of reducing the costs of default}

\subsection{Are default costs too high?}

The critical reaction by the creditor community to proposals for an international bankruptcy procedure reflects the presumption that default costs will be reduced (see below). However, this might lead to ex ante inefficiencies, even if creditors are not themselves worse off ex post. A reduction in default costs may make default more likely. Assuming that more frequent defaults are anticipated, lenders will lend less and/or charge a higher risk premium, to the possible detriment of the developing world.

There is some evidence that these effects exist in the personal bankruptcy sphere, which, as argued above, shares some similarities with sovereign bankruptcy. Because exemption limits under Chapter 7 (liquidation) of the US Code vary across states, it is possible to gauge the effects of relatively generous limits. Gropp et al. (1997) show that households in the bottom part of the asset distribution hold less debt as exemptions become more generous, suggesting that there is a credit supply effect. Moreover they pay higher interest on automobile loans. There is scant evidence in the sovereign context, although a study by Eichengreen and Mody (2000) found that countries that issued debt under UK law rather than under US law pay a higher interest rate on average if their risk rating is high, although in fact the opposite is the case for countries with a lower risk rating. Because it is easier to restructure under UK law, this might suggest that for problem countries, an efficient bankruptcy procedure will add to interest costs. (However, there might be a signalling effect; see below.)

The idea that default must be costly for the effective functioning of international capital markets can be traced back to the formal model of Eaton and Gersovitz (1981). These ideas are acknowledged in the current debate (e.g., Cline (2002) regards the 'EatonGersovitz theory on the need for default pain as quai-collateral in the absence of physical capital' as one of the conceptual underpinnings of crisis resolution). A number of commentators appear to take an ambiguous position on default costs:

Some people see these costs as necessary to discipline debtors to avoid default. Bankruptcy should be messy, they say! In the view of many, however, the costs incurred under the current international financial architecture are unnecessarily large... (Boorman 2002).

This tension is also apparent in theoretical discussions of crisis management:

Thus, debt restructuring must be costly to reduce opportunistic defaults but not too costly as there are (unobserved) cases of inability to pay 
(insolvency) where restructuring should have been orderly for the benefit of all parties (Roubini 2002: 14).

Thus there is no consensus on whether current default costs are too high or too low. For some, though, the position is clear. Rather than being concerned about a trade-off between costs incurred by defaulting debtors and the amount they can borrow, it is argued that debtors are already borrowing too much. They argue that the erosion of sovereign immunity may have made borrowing too easy. The use of UK and US law, and the legal infrastructures of other developed countries, by weakening sovereign immunity, implies that developing countries can borrow more than would be possible if all borrowing took place under the jurisdiction of their own courts, to the possible detriment of welfare. This is argued by Bulow and Rogoff (1990) and reiterated recently by Bulow (2002: 2):

The US should repeal the relevant portion of the Foreign Sovereign Immunity Act Return of 1974 and the UK the part of the 1976 State Immunity Act that allows developing countries to waive their immunity when they borrow money abroad. That is, the entire jurisdiction over any sovereign's debts would lie in its domestic legal system. The other leading economic powers should follow suit, though unanimity would probably not be needed.

Using the jurisdictions of developed countries allows sovereigns to raise more money than they could manage otherwise to raise by making default more difficult/costly. This is particularly relevant, if, as argued by the more radical critics of the current international financial architecture, many developing countries will attempt to borrow too much because the sovereign decisionmaker's interests do not coincide with those of the rest of the country. 16 (This may be due, for example, to corrupt rulers siphoning off some of the borrowed funds, self-serving elites who do not suffer the full costs of repayment/default, or decisionmakers who serve interest groups but who anticipate that the costs of repayment will fall more heavily on other interest groups; see Alesina and Tabellini 1989, for a model of this latter type.)

A similar point can be made about the choice between UK and US law. Issuing bonds under UK law, with its collective action provisions, might be seen as a way of improving efficiency if a default occurs further down the line. The fact that countries prefer not to do this in general or at least exclusively, but use US or other jurisdictions, might be seen as an indication that they want to increase the disruption that might occur if they end up in difficulties.

How should we interpret the fact that sovereigns appear to prefer to make default more costly? This might be because increasing default costs is genuinely a good idea, even if

16 Overborrowing can also occur because of informational asymmetries. Kletzer (1984) showed how, if creditors are unable to monitor the total amount of lending to a country, then the country will borrow more than would otherwise be the case. The intuitive argument is that while the country would prefer to commit to a lower level of lending, which would entail a lower level of default, and hence a low risk premium, this outcome is unsustainable when lenders cannot observe total lending. Starting from this putative equilibrium, with a low risk premium, the country would prefer to borrow more, and anticipating this, lenders will charge a higher risk premium. Nevertheless, in equilibrium there will be higher lending and a higher default risk than would be the case with the observability. The country is worse-off. 
this is achieved by making the legal position murkier, because it allows the country to borrow more. If this view is correct, we might indeed worry that reform attempts are just going in the wrong direction. Or, it might be that sovereigns are irresponsibly attempting to overborrow, as just discussed, in which case the reform might be going in the right direction. A third possibility is that there some 'signalling' going on here. A country that refuses to waive sovereign immunity would be signalling that it anticipates a likely default. The equilibrium is a pooling one in which all types, those who are not likely to default and also those who are, choose to waive immunity (or issue under US law), in order to reduce borrowing costs. The signal is uninformative but the equilibrium would be inefficient because of the increased default costs for the latter category. 17

To summarize: if it is true that there is overborrowing, then a sovereign bankruptcy procedure, assuming it makes default less costly (see below), is likely to improve matters by making lenders more cautious. The opposite may be true if there is underborrowing, as one interpretation of the use of foreign jurisdictions (especially the use of US law) in international lending suggests. Even in this case, however, if the procedure reduces the deadweight loss involved in default so that the lowered debtor costs are not at the expense of creditors, lending terms may not deteriorate unless the probability of default rises. And even if lending terms do deteriorate, there is a trade-off between the ability to borrow less and incurring lower costs in case of default. The issue is examined in detail in Section 5.

\subsection{Will a bankruptcy procedure lead to more default?}

Any bankruptcy procedure, even of the Krueger type, is likely to make default less costly. There are a number reasons for this. First, the inefficiencies associated with payments crises should be diminished. New (i.e., post default) lending would be easier to come by under the proposals, as already discussed. The temporary stay should reduce the chances of a currency crisis developing. A faster, more orderly process will surely reduce costs of disruption to the local economy. (It is argued, as in the case of Argentina recently, that current arrangements encourage sovereigns to put off the evil day of reckoning as long as is possible, in order not to upset creditors, but to the ultimate detriment of all parties' interests.) Second, the amount that creditors can expect to receive may go down. The resolution of collective action problems might tilt bargaining power in favour of the debtor: those creditors attempting to hold out for the best deal can be outvoted by a (super)majority of the others. Likewise rogue creditors will have less power to extract payment. By reducing the moral hazard problem (see Section 1), the creditors may be forced to take larger losses, with the debtor not being left having to repay further loans to the IMF.18 In general, as Cline (2002) argues, an international bankruptcy court in which the international official sector plays a role is likely to bring

17 Indeed it has been observed that countries with some question about their debt sustainability do seem to issue debt under US law.

18 For a sketch of a model in which standstills can ex post benefit debtors at the expense of creditors' interests, see Eaton (2002). 
in a political dimension to decision-making. Private creditors will perceive that once political considerations play a role, the cards 'will be stacked' against them. 19

Indeed, even though the Krueger proposal goes to great lengths to reassure creditors that their interests will be protected, it is an avowed aim of the SDRM to reduce the costs imposed on the debtor. 20 Krueger (2002a) herself denies that this will create an increased likelihood of default:

[S]ome commentators fear that alleviating the collective action problems will make default an easy way out. But the prospect of economic dislocation, political upheaval, and possible long-term loss of access to international capital markets will still make countries loth to default on debt service obligations in all but the most extreme circumstances.

The Krueger view seems to deny the possibility of opportunistic behaviour on the part of countries, regarding payments crises as exogenous events. 21

This opinion does not appear to be shared by the financial community. For example, William Rhodes (senior vice chairman of Citygroup, Citicorp and Citibank) argues that the main concern of a number officials in emerging markets countries is that the existence of a formal bankruptcy mechanism, whether invoked or not, would cause uncertainty in the markets, deter potential lenders and investors, and drive up the countries' borrowing costs. 22

John Taylor (2002) has expressed a similar concern that any reform should beware of opportunistic behaviour: 'Most importantly, any proposals should in no way "disincentivise" a government from paying its debt'.

While, then, there is considerable disagreement on this matter, the point should be made that a cut in the bargaining power of creditors due to a formal bankruptcy process, will probably lead to increased risk premiums and lowered borrowing capacity

19 He also disputes the idea that the private sector would welcome a formal mechanism because it leads to a reduction in uncertainty.

20 Elsewhere, however, it appears the aim of the mechanism is to allow creditors to extract the maximum sustainable payment from the sovereign. At least this is implicit in Krueger (2002), where it is noted that corporate bankruptcy procedures serve to maximize the value of creditor claims (p.11). In qualifying how corporate procedures might be translated into the sovereign debt context, this point remains unqualified. On the other hand she notes that in some respects Chapter 9 for municipalities might be of more relevance, which suggests other priorities. Also ideas such as debt sustainability and restoring growth to the debtor probably reflect her view of the limits to what can be paid by the debtor. A further point is that, as discussed elsewhere in the paper, the Chapter 11 procedure is actually generous to debtors by international comparison.

21 Even if opportunistic behaviour is absent, it should be noted that if the bankruptcy procedure leads to larger debt write-downs when default does occur, lending can fall and interest rates rise as banks anticipate lower repayments. Also, there may be a moral hazard problem in that the debtor may, if default becomes less costly, take prior actions (such as a failure to engage in costly reforms) that increase the probability of the country ending up unable to service its debts, even though there is not an opportunistic default decision.

22 William Rhodes, 'The drawbacks for plan orderly rescue: they formal bankruptcy procedure for countries facing economic crisis would be inefficient and damaging' (The Financial Times, 22 March 2002: 13). 
independently of the question of whether the rate of default is likely to rise. And even if capital flows do fall, it may still be a price worth paying for better outcomes for debtors in bad states.

\section{$5 \quad$ A simple model of debt and default}

In this section I will develop a simple two-period model in which a sovereign borrows in the first period to provide for investment and current consumption. In the second period it receives output from the previous investment, and makes a decision on whether to repay its debt or not. While simple, this model incorporates many of the features that have featured in recent discussions. Investment can be inefficiently low in period 1 because the sovereign is unable to borrow sufficient funds due to an inability to commit to repay. This can depress investment (reducing period 2 output and hence further reducing the amount it can borrow). Alternatively, investment may be depressed because an overhang of debt implies that the country does not receive the full marginal return on sacrificing period 1 consumption. If there is a state of nature in which default occurs, then some of the return from investment will go to creditors under the assumptions made below. The question that I want to address is how a shift in terms and costs of any restructuring affect variables of interest, and in particular debtor welfare (since lenders will be assumed to make zero profits in equilibrium, their welfare is fixed). Is it true that, as often claimed, a shift in favour of the debtor will reduce lending, depress investment, and be to the detriment of welfare?

While a contract with a contingent repayment would be 'first best', I assume that contracts are not complete. Specifically, only a standard debt contract is available, specifying a fixed repayment. If the borrower chooses not to repay, then I assume that the resolution process consists of two elements. First there is a cost (calculated in terms of current consumption) imposed on the debtor of $C$. This is independent of other values, and represents the disruption caused during the resolution process, such as difficulties obtaining trade credit, costs of internal payments systems failures, etc. 23 It is a deadweight loss. Second, it is assumed that the resolution process leads to a fraction $\beta$ of output going to creditors. Thus $\beta$ may represent the bargaining strength of the creditor community, or the procedure to be followed by a bankruptcy court. Such a fractional division of output assumption is fairly standard in the literature, and may result from a standard bargaining model. Alternatively in any resolution process, it may be supposed that lower output will lead to a smaller repayment to the creditors, and we are assuming the relationship to be linear. Both $C$ and $\beta$ will depend on whether there is some kind of bankruptcy procedure at all, and what form it takes if there is one. Under a bankruptcy procedure, $C$ should be lowered relative to the status quo. One would suppose that the Pettifor proposal would lead to a lower level of $\beta$ than that of Krueger.

23 It might also include costs suffered to future reputation, though in a two period model such considerations are not strictly relevant. There is no equivalent cost on the creditors on the supposition that they are only interested in the amount that they eventually can reclaim. 
Lenders will be treated as a competitive but monolithic entity, and thus I am sidestepping all the issues concerned with lender coordination. 24 This simple model also sidesteps issues to do with IFI involvement, that is to say, the questions of moral hazard and bail outs.

In period 1, a sovereign country receives an endowment $\omega_{1}$ of a single perishable good, and borrows an amount $L$ from abroad. It splits its current gross resources $\omega_{1}+L$ between current consumption $c_{1}$ and capital investment $k$. It is supposed that $k$ is not under the control of the lender. In period 2, an exogenous shock occurs. Assume that a state $s$ is drawn from a continuous distribution with strictly positive density $h(s)$ on some support $[\underline{s}, \bar{s}]$. Gross output in state $s$ is $f(k, s)$, where $f(k, s)$ is a statedependent production function, and $\partial f / \partial s>0$. The sovereign has a utility function $u\left(c_{1}\right)+v\left(c_{2}(s)\right)$, where $c_{i}$ is consumption in period $i$, and maximizes expected utility. It is assumed to be risk averse, so that $u(\cdot)$ and $v(\cdot)$ are both concave functions. It is assumed that lenders are competitive, risk-neutral, and that the world interest rate is $r$. This implies that for lenders to be in equilibrium, expected repayments must equal $L(1+r)$. Subject to this constraint, the borrower will seek to borrow an amount that maximizes expected utility.

As a benchmark, I look first at the case where contracts are enforceable. In this case a state dependent repayment $R(s)$ can be specified for period 2. Then the borrower chooses $L, k$ and $R(s)$ to solve the following:

$$
\operatorname{Max}_{L, k, R(s)} E_{s}\left[u\left(\omega_{1}+L-k\right)+v(f(k, s)-R(s))\right]
$$

subject to

$$
E_{s}[R(s)]=L(1+r)
$$

Solving this, we get the condition

$$
1+r=E\left[f^{\prime}(k, s)\right]
$$

and

$$
u^{\prime}\left(c_{1}\right)=(1+r) v^{\prime}\left(c_{2}(s)\right) \quad \text { all } s .
$$

Consequently $k$ is chosen to maximize the discounted value of output, consumption is stabilized across states in period 2; and marginal utility declines at rate $(1+r)^{-1}$ between the two periods. Thus, there is production efficiency and perfect insurance.

Next assume a standard debt contract with fixed repayment $R$ due in period 2. The country then chooses whether to repay its debt, implying that consumption

24 As mentioned above, mechanisms for dealing with collective action problems almost certainly do affect the balance of power in any negotiations. Thus I am treating such effects as being subsumed into the value of $\beta$. 
$c_{2}(s)=f(k, s)-R$, or to default. The consumption of the debtor in the event of default is therefore $(1-\beta) f(k, s)-C$. With a single (i.e., not state contingent) repayment $R$, insurance can only be obtained by having default in some states. The sovereign in such states chooses to repay less than $R$. This it can do but of course it cannot control the payment (in the model); it will pay $\beta f(k, s)$ and additionally suffer the cost $C$. The point is that in this case, having lower default costs might lead to a reasonable outcome in the absence of state contingent repayment possibilities. Having a very costly process (high $C$ ) or one in which creditors have high bargaining power (high $\beta$ ) is not obviously desirable, since although default will be discouraged, when the country can least afford it, i.e., in low output states, it may be faced either with having to repay its debt in full or suffering a high default cost.

To illustrate the point, consider the following very simple example. There are two states which occur with equal probability and which we denote by $i=B, G$. There is no investment possibility (i.e., $f(k, s)$ is independent of $k$ and simply represents the period 2 endowment) and the interest rate is zero. Per-period utility is given by a piecewise linear function with slope equal to 2 for $c_{t}<10$ and slope of 1 for $c_{t} \geq 10$ (period 2 utility is not discounted). Period 1 endowment is 0 , while period 2 endowments are 10 and 100 in the respective states $B$ and $G$. Finally, suppose that $C=0$ (no deadweight bargaining cost).

Ideally, the country would like to shift some of the endowment of 100 in the $G$ state (low marginal utility) to period 1 (high marginal utility). It wants to make sure that consumption is at least 10 in each period and state. With binding contingent contracts this would require, for example, a loan of $L=10$, paid back with a repayment of 20 in the $G$ state, but no repayment in state $B .25$ (This yields zero profits to the lender.) Next, with standard debt contracts, suppose that $\beta=0.5$, so that in any default creditors can bargain one half of current output out of the sovereign. The problem now is that any $L>0$ will lead to some repayment in state $B$, which is sub-optimal since it leads to a marginal utility of consumption of 2 in that state. The best that can be done is again to set $L=10$, but now we will have a default in state $B$ yielding a repayment of $0.5 \times 10=5$. For zero profits, $R=15.26$ Consider, however, a reduction in the creditors' bargaining power to $\beta=0.2$. Now, a loan of $L=10$ leads to a repayment in the default state of only 2 , while $R=18$ (since creditors can bargain out 20 in the good state, the sovereign will choose to repay in that state). Hence $c_{2}^{B}=8$, whereas previously it was $c_{2}^{B}=5$. (Sovereign utility is 1.5 units higher.) The weaker bargaining power of the creditors allows the debtor to retain a higher income in the bad state in which it is going to default anyway.

25 Any higher $L$ up to 45 , with a repayment of $2 L$, is equally good.

26 This is optimal, as for each extra 1 unit borrowed up to 10 , there is a marginal utility in period 1 of 2 , while the cost in terms of future expected marginal utility will be either $0.5 \times 2+0.5 \times 1=1.5$ if there is no default ( $L \leq 5$; here, for zero profits, $R=L$ or $0.5 \times 0+0.5 \times 2=1$ if there is default $(L>5$; in this case repayment in state $L$ is constant at 5 , so increases in $L$ only affect consumption in state $H$ ). In either case, the current utility gain exceeds the cost, until $L=10$, where they are equal. 
It is useful to briefly consider the salient features of this example, as we shall find that the lesson to be drawn carries over to some extent to the more general model. The problem facing the sovereign is essentially one of transferring income from an abundant future state to the present. With complete contingent contracts this is straightforward. In their absence, and using a debt contract, the difficulty involved in mortgaging the future income in the abundant state of the world is that it also implies a claim on income in the bad future state. The larger the bargaining power of creditors, the bigger that claim is going to be. Note that in the example, for a large range of values of $\beta$, there is no difficulty borrowing the required amount (of 10). Hence the sovereign's borrowing capacity is quite adequate for this range. In more realistic scenarios, we might imagine this not to be the case. Then increasing the value of $\beta$ will increase the borrowing capacity, which will of itself be a beneficial thing. So an increase in $\beta$ might well have an ambiguous effect, even when there is a future state in which default occurs and from which ideally we would like to transfer repayments to some better state. In simulations of the more general model we shall see that it is primarily in cases where the borrowing capacity is sufficient or close to being sufficient that a shift in bargaining power to the sovereign is desirable.

We can write the general problem with debt contracts as follows:

$$
\operatorname{Max}_{L, R} E_{s}\left[u\left(\omega_{1}+L-k\right)+v(f(k, s)-R(s)-C(s))\right]
$$

subject to

$$
E[R(s)]=L(1+r)
$$

where for all states $s$ :

$$
\begin{aligned}
& R(s) \equiv\left\{\begin{array}{cc}
R & \text { if } R \leq \beta f(k, s)+C \\
\beta f(k, s) & \text { if } R>\beta f(k, s)+C
\end{array}\right\}, \\
& C(s) \equiv\left\{\begin{array}{ll}
0 & \text { if } R \leq \beta f(k, s)+C \\
C & \text { if } R>\beta f(k, s)+C
\end{array}\right\}
\end{aligned}
$$

and $k$ solves

$$
\operatorname{Max}_{k} E_{s}\left[u\left(\omega_{1}+L-k\right)+v(f(k, s)-R(s)-C(s))\right]
$$

subject to (2) and (3).

In other words, (2) represents the repayment made according to the ex post optimal default decision by the sovereign, while (3) represents the corresponding bargaining costs which are incurred in the case of default. For any choice of $L$ and $R$, i.e., for any debt contract, the country will optimize, by choice of $k$, its utility. Anticipating this, the lender must be guaranteed zero profits, by (1). The best $(L, R)$ package is chosen subject to this zero profit constraint. 


\subsection{No deadweight costs, no investment}

I start with the simplest case where $C=0$ (no deadweight costs) and no variable investment (take $k$ to be fixed). Intuitively we might expect a reduction in $\beta$, the share going to creditors, to be beneficial in that it increases consumption in the worst (default) states of the world, at a cost to consumption in the best (payback) states. This is confirmed provided that the sovereign is not debt capacity constrained, by which is meant $L$ could be increased if the sovereign wished.

For notational simplicity we can treat period 2 output as the random variable, and so let $y=f(k, s)$, and let $g$ be the density for $y$. Assume there is an interior solution for the point of default, $y^{*}$, so that $y^{*} \in(\underline{y}, \bar{y})$. This is equivalent to assuming that the sovereign is not debt capacity constrained. Then the sovereign will default if $y<y^{*}$ where $y^{*}$ is defined by

$$
R=\beta y^{*}
$$

Then country utility is

$$
U=\int_{\underline{y}}^{y^{*}} v((1-\beta) y) g(y) d y+\int_{y^{*}}^{\bar{y}} v(y-R) g(y) d y .
$$

The zero profit constraint (1) is

$$
\int_{\underline{y}}^{y^{*}} \beta y g(y) d y+\int_{y^{*}}^{\bar{y}} \operatorname{Rg}(y) d y=L(1+r) .
$$

In the following, $L$ is held constant. Differentiating (5), we get (using (4)):

$$
\frac{d U}{d \beta}=-\int_{\underline{y}}^{y^{*}} v^{\prime}((1-\beta) y) y g(y) d y-\frac{d R}{d \beta} \int_{y^{*}}^{\bar{y}} v^{\prime}(y-R) g(y) d y,
$$

and differentiating (6), we get (again using (4)):

$$
\int_{\underline{y}}^{y^{*}} y g(y) d y+\frac{d R}{d \beta} \int_{y^{*}}^{\bar{y}} g(y) d y=0 .
$$

Hence

$$
\frac{d U}{d \beta}=-\int_{\underline{y}}^{y^{y^{*}}} v^{\prime}((1-\beta) y) y g(y) d y+\frac{\int_{\underline{y}}^{y^{*}} y g(y) d y}{\int_{y^{*}}^{y} g(y) d y} \int_{y^{*}}^{\bar{y}} v^{\prime}(y-R) g(y) d y
$$

and thus as $\int_{\underline{y}}^{y^{*}} y g(y) d y>0$, 


$$
\operatorname{sign}\left[\frac{d U}{d \beta}\right]=\operatorname{sign}\left[-\frac{\int_{\underline{y}}^{y^{*}} v^{\prime}((1-\beta) y) y g(y) d y}{\int_{\underline{y}}^{y^{*}} y g(y) d y}+\frac{\int_{y^{*}}^{\bar{y}} v^{\prime}(y-R) g(y) d y}{\int_{y^{*}}^{\bar{y}} g(y) d y}\right] .
$$

Thus by the concavity of $v, v^{\prime}$ is decreasing and so $\frac{d U}{d \beta}<0$. This is holding $L$ constant. Since the sovereign can always choose this level of $L$, but may be able to do better, we can conclude that provided the sovereign is not debt capacity constrained, a shift in bargaining power in favour of the sovereign is beneficial.

Intuitively, if $\beta$ falls, there is a shift in repayment from bad states where the marginal utility of income is high, to good states where it is low. Since there is no deadweight loss associated with default, there are no additional costs with an increase in the default rate merely affecting the distribution of repayments across states. The result however does not hold if the sovereign is debt capacity constrained (with $y^{*}=\bar{y}$ ) since it is no longer true that $L$ can be held constant as $\beta$ falls: the maximum amount that can be borrowed against period 2 income must fall. It is then possible that period 1 marginal utility of income is sufficiently high that a fall in $L$ more than offsets the period 2 gains.

\subsection{Deadweight costs, no investment}

The argument above no longer applies when there are deadweight costs present $(C>0)$. The reason is that as $\beta$ falls, $y^{*}$ rises, implying that deadweight costs are incurred more frequently. Hence the result becomes ambiguous. In fact, perhaps more surprisingly, even a reduction in $C$ may be welfare reducing.

Suppose that the debtor is risk-neutral in period 2 (i.e., $v(\cdot)$ is linear), and again assume that $k$ is fixed. Hold $L$ constant. Assume an interior solution for $y^{*}$, the point of default. It is now determined by the condition $R=\beta y^{*}+C$. First, if $\beta$ falls, $y^{*}$ rises (and $R$ also must rise, further increasing $y^{*}$ ). Consequently, total deadweight costs increase, and this burden falls fully on the sovereign (the lender always make zero profits). With a risk-neutral sovereign in period 2 , utility falls by the increase in deadweight loss. Since this argument holds for all values of $L$ such that $y^{*}$, is interior, the sovereign cannot undo this effect by changing $L$ (and the maximum value of $L$, such that $y^{*}=\bar{y}$, is no longer sustainable). Second, if $C$ falls, $y^{*}$ again rises (and $R$ also rises, further increasing $y^{*}$ ). Whether aggregate expected deadweight costs rise or fall (which is what matters for sovereign welfare) depends now on the distribution of $y$. Suppose that the density puts very little weight in the interval between the old and new values of $y^{*}$. Then there is (approximately) no increase in deadweight costs due to the increase in $y^{*}$, but there will be a decrease over the range $\left(y, y^{*}\right)$ due to a fall in $C$, and the latter effect dominates. Alternatively, by putting a large enough 'spike' in the density at $y^{*}$, this argument can be reversed. The conclusion then is that with a period 2 risk-neutral sovereign, and $C>0$, a cut in $\beta$ is bad for welfare even when $y^{*}$ is 
interior, while a cut in $C$ has ambiguous effects. By continuity a similar argument can be made when $v(\cdot)$ is slightly concave.

\subsection{Two-state simulation}

To proceed further, and to consider the effects of variable $k$, I simulated a discrete, two state, version of this model, with $u(\cdot)=\log (\cdot)$ and $v(\cdot)=\delta \log (\cdot)$, and

$$
f(k, s)=\left\{\begin{array}{ll}
\gamma \rho k+\theta_{B} & \text { if } s=B \\
\rho k+\theta_{G} & \text { if } s=G
\end{array}\right\} .
$$

This linear production function was chosen for computational simplicity, and although it would imply no finite solution in the complete contracts model if the average return to investment exceeds the interest rate, this will not generally be an issue in the model with default options. The $B$ state will represent a low output state, and it will be assumed that both $\gamma<1$ and $\theta_{B}<\theta_{G}$.

I shall refer to a default solution as an optimum contract where default occurs only in state $B$. Further, define a default solution to be debt capacity constrained in this case if the sovereign would benefit from a higher loan assuming the possibility of default in state $G$ could be ruled out, and assuming the lender makes zero profits. It can be seen that being debt capacity constrained implies that in state $G$, the default option is exactly as attractive as repayment $(R=\beta f(k, G)+C)$.

Even if the sovereign is slightly debt capacity constrained, a cut in $\beta$ can be beneficial. Take, for example, the parameter values: $\delta=0.9 ; r=0 ; \pi_{B}=0.1 ; \pi_{G}=0.9 ; \quad \beta=0.4$; $C=2 ; \omega_{1}=10 ; \theta_{B}=7 ; \theta_{G}=37 ; \gamma=0.5 ; \rho=0.95$.

In Figure 1, the darker line represents the sovereign's utility in the default solution (i.e., it assumes that there is default only in the bad state). The dotted line represents the utility that would be obtained from a default in the good state; provided this is lower than the former then there is no incentive to default. As can be seen, they cross at approximately $L=15.7$, at which point utility is still rising. So it pays the sovereign to go right up to that constraint: it is therefore debt capacity constrained. The lighter line at low loan levels represents the utility that would be had from a contract in which no default takes place. This requires a much lower loan—at best $L=3.5$. For much higher loans the incentive to default in the bad state becomes too large and so the contract is unsustainable. So this contract suffers because it is unable to raise much in the way of loans, 27 and period 1 consumption is very low relative to period 2 state $G$, whereas in the default solution this is not true. It does benefit, however, from avoiding the default $\operatorname{cost} C$, which is of course just a deadweight loss. Nevertheless, overall, the default solution is preferable. In the latter, most of the loan is in fact used for period 1 consumption, and investment is relatively low at approximately $k=2.7$. At these parameter values, we have the effect on expected utility to be $\partial E U / \partial \beta \cong-0.6$.

27 In fact in many simulations the debt capacity constraint is not reached because full repayment in the bad state makes too large a loan undesirable, even if repayment is credible. 


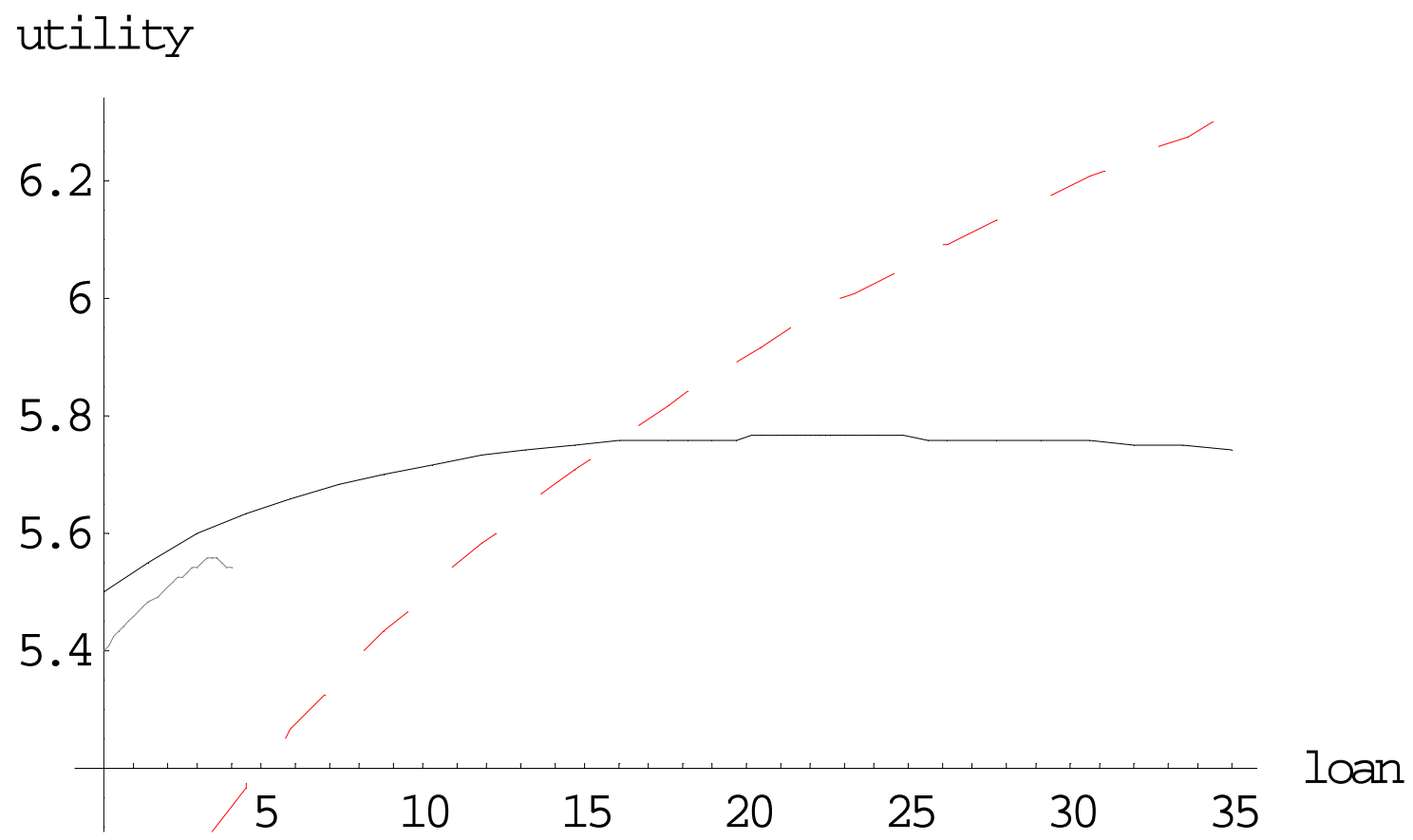

This example resembles the simple example presented earlier. Despite the presence of an investment opportunity, in the equilibrium $k$ is quite low (the average return on investment is below the interest rate; investment takes place in order to boost consumption in the bad state). Likewise, although the debt capacity constraint is binding, the advantage of extra loans is not very big in utility terms. Thus reducing $\beta$ can be advantageous in such situations. In fact we find that the best value for $\beta$ is approximately 0.32 (with $k=0$ ).

The simulations demonstrate, on the other hand, that as the debt capacity constraint binds more tightly, for example as the return on investment is increased, the advantages of higher values for $\beta$ in terms of allowing higher loans are more likely to outweigh the disadvantages. For example, if in the above example the return on investment is increased, specifically if $\rho$ is increased from 0.95 to 1 , the optimum value of $\beta$ increases from 0.32 to 0.46 . Hence for values of $\beta$ in between 0.32 and 0.46 , the sign of $\partial E U / \partial \beta$ will switch from being negative to positive.

Another case where increases in $\beta$ can have adverse consequences is when consumption in the bad state is so low that increases in $\beta$ which cut consumption in this state, can be adverse even though investment is highly productive. The problem arises if, as debt capacity is increased (allowing more borrowing), the extra output in the bad state due to any increased investment is not enough to compensate for the extra output being extracted by creditors. For this simulation, we choose $p=4$, but $\gamma$ is chosen close to zero $(\gamma=0.001)$ so the return on investment in the bad state is virtually zero. We also choose $\theta_{B}=4$ to be fairly close to $C$, so that consumption in this state is very low in the event of default as $\beta$ approaches a critical value (of 0.5 ). Other 
parameter values are $\delta=0.9 ; r=0 ; \pi_{B}=0.5 ; \pi_{G}=0.5 ; C=2 ; \omega_{1}=1 ; \theta_{G}=44$. In Figure 2 I plot the utility curves for $\beta=0.2$, shown as the higher curves, and for $\beta=0.4$, shown as the lower, thicker curves. The utility curve for the no-default contract does not vary with $\beta$ (no debt constraint). As can be seen, the higher value of $\beta$ allows a higher loan (given by the crossing point of the solid and broken lines: the country is debt capacity constrained in both cases), but utility falls.

In Figure 3 the solid line shows utility from the default contract, while the broken line shows that from the no-default contract. As can be seen, at very low levels of $\beta$ the latter contract is preferable: borrowing capacity is very low anyway and there is little gain from borrowing up to full capacity if this implies incurring $C$ in the bad state. When $\beta$ is close to 0.5 , consumption in the bad state under a default contract goes to zero (and utility to $-\infty$ ), and again the no default contract is preferable. 28

Figure 2

Another case where increases in $\beta$ harm welfare.

\section{utility}

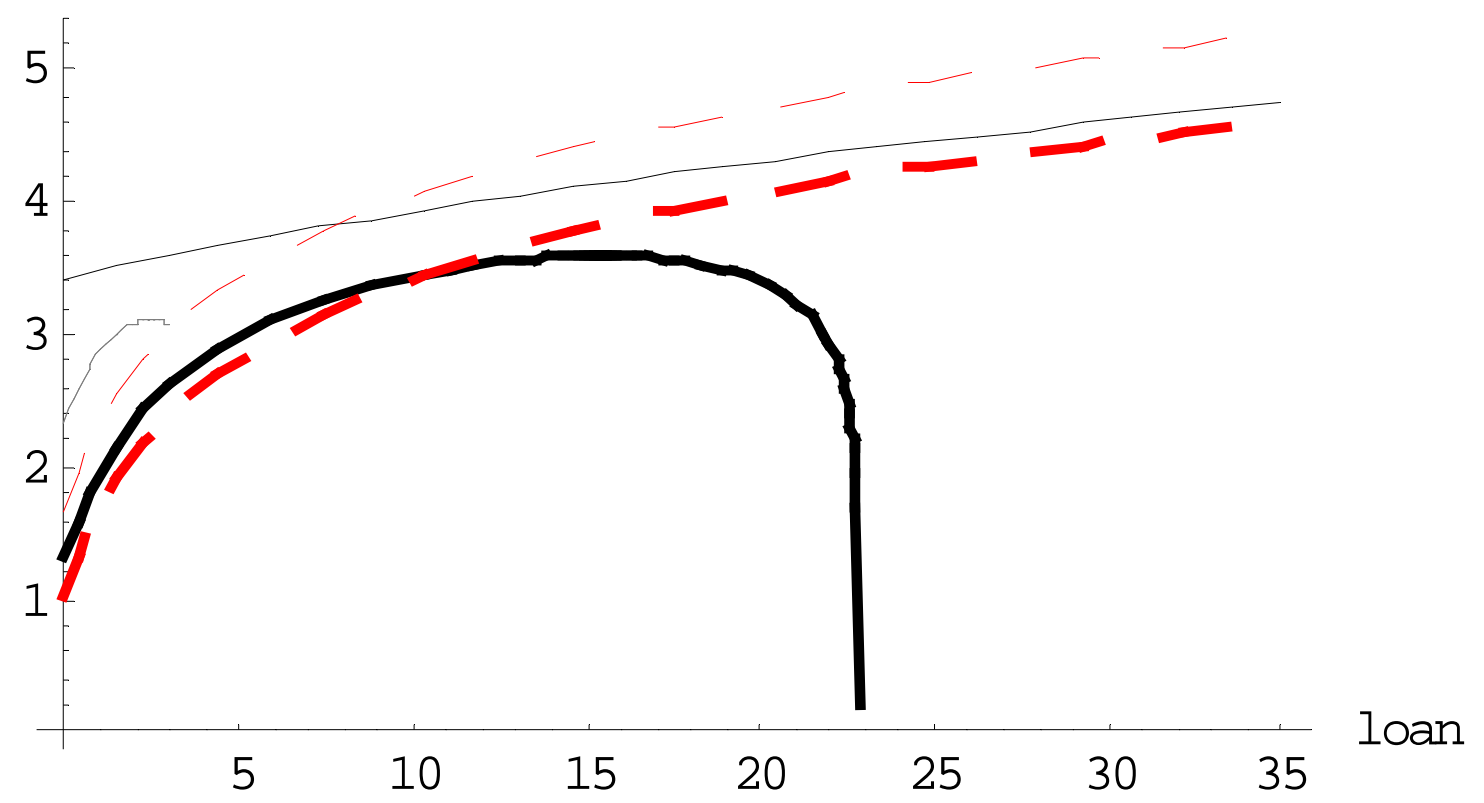

28 While the logic of this example would seem to suggest that similar issues should always arise whenever increases in $\beta$ reduce consumption in the bad state towards zero despite any increase in output due to higher investment, in practice in such cases the no default contract often dominates the default one. In that case, the effect of $\beta$ is likely to be small or non-existent (as it is much likely that in a no default contract the sovereign is not debt capacity constrained, so increases in $\beta$ have no effect). What one can say is that if $\beta$ has this effect on the default contract, and the default contract is optimal for some values of $\beta$, then there will be a range of values for which utility is declining in $\beta$, since the default utility curve must cross below the no-default on at some point (assuming the latter is independent of $\beta$ ). 


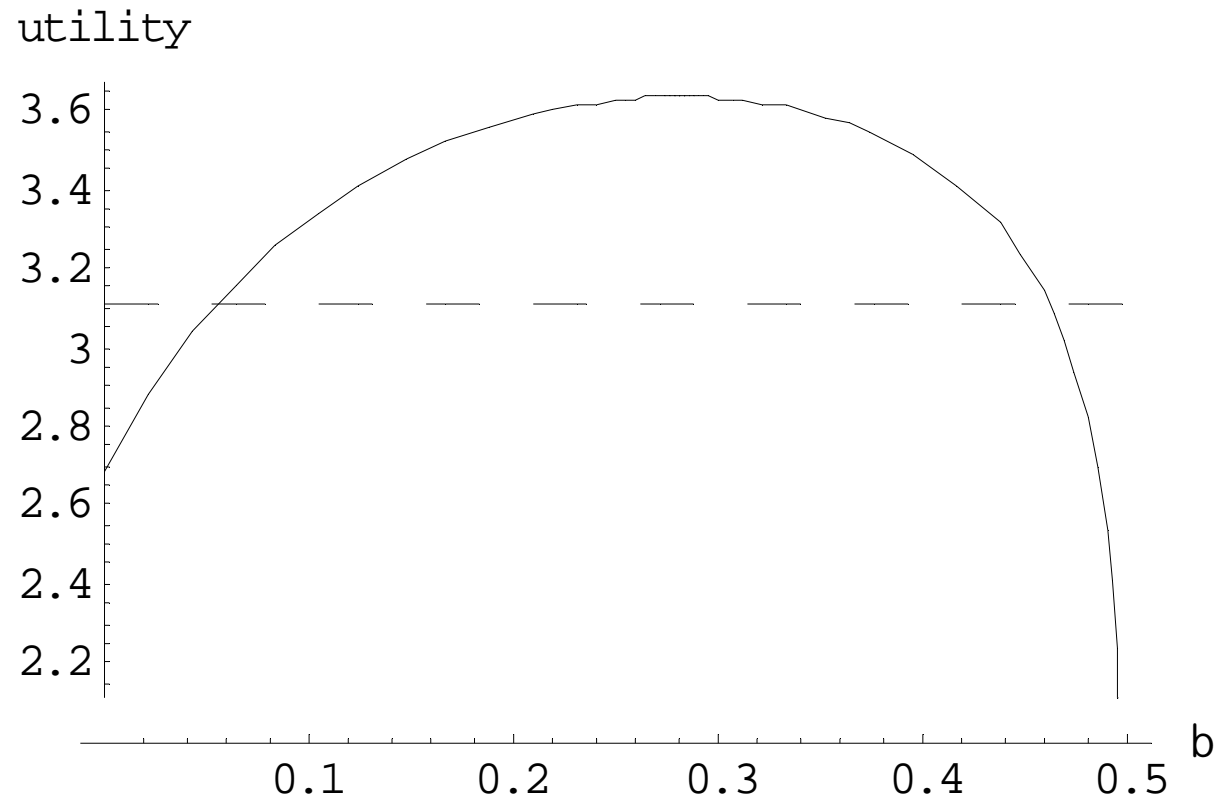

It should be stressed, however, that simulations suggest, at least in our simple model, that sovereigns with debt capacity constraints are in most circumstances likely to prefer to cede bargaining power to creditors in order to allow the borrowing capacity to increase. It might nevertheless be asked whether this remains true when the sovereign cannot reasonably be represented as a rational utility maximizing monolith. Specifically, and to keep matters simple, suppose that decisions in period 1 (concerning $L$ and $k$ ) are taken by an impatient decisionmaker, that is, one who is less patient than the true preferences of society would indicate. This could represent a government whose popularity depends unduly on current consumption. It might alternatively be a short hand for decisionmakers who seek to raise as much as possible in loans in order to boost a particular constituency's current consumption, given that they cannot be sure that they will be in power next period (see Alesina and Tabellini 1989). The issue now is whether, even in the presence of strongly debt-capacity constrained debtors, an increase in the value of $\beta$ might be disadvantageous to social welfare. The idea is simply that the impatient sovereign will borrow all it can, mostly for current consumption, with little heed for the future (i.e., underinvestment). In a bad state of nature in period 2 , and being unable to repay all its debt, any increase in the bargaining power of creditors could be disastrous. The impatient period 1 decisionmaker does little to provide investment that might alleviate the predicament. 29

29 In a sense, this might paint too favourable a picture of increases in creditor bargaining power. If higher debt levels imply that higher payments can be extracted from a defaulting borrower, as is suggested for example by the regression analysis in Eaton (1990), any increase in bargaining power and hence borrowing capacity would lead to further cuts in consumption in bad states. Note however that the simple fixed bargaining cost and proportional extraction ability of creditors, assumed here in common with much of the literature, does not have this feature. 
To construct a bald example of this, change the previous parameter values so that now $\delta$ is close to zero: $\delta=0.01$; however, social welfare will be evaluated using $\delta=0.9$ again. In addition, choose $\theta_{B}$ to be close to $C$, so that consumption in this state is very low in the event of default: $\theta_{B}=4$, as in the last example. Other parameter values are $r=0 ; \pi_{B}=0.5 ; \pi_{G}=0.5 ; \quad C=2 ; \omega_{1}=10 ; \theta_{G}=10 ; \gamma=0.1 ; \rho=1.2$. This example is different in that with social preferences the incentive to transfer consumption to period 1 is much reduced. The impatient decisionmaker will in general of course raise as much $L$ as it can, and spend most or all on current consumption. In this example, if $\beta=0.5$, and in the absence of positive investment, consumption in the bad state (assuming default) would be zero. So for $\beta$ close to 0.5 , we might expect a negative effect on consumption in this state to dominate social welfare. Indeed in this case, we find that above $\beta=0.42$, social welfare is declining for the reasons already mentioned. How does this compare with the same model but with the decisionmaker sharing the social time preference? If one looks at the default solution, welfare is only decreasing in $\beta$ for values extremely close to 0.5 , but in fact this is dominated by a no default contract (in fact, one where $L=0) .30$ Thus, for this example, the presence of an impatient decisionmaker leads to a high level of borrowing and the possibility that increasing the bargaining power of creditors is harmful to social welfare. Another aspect of this is that the impatient decisionmaker, not surprisingly, does prefer a higher value of $\beta$ for all values except those extremely close to 0.5 , even if this is harmful for social welfare. We can relate this to the observation that countries do not choose to issue bond contracts solely under UK law, which, as we have seen, has the benefit of allowing collective action clauses, and which additionally offers immunity for a sovereign's assets held abroad but used for commercial purposes. (Under US law, only assets used for sovereign purposes, such as embassies, have immunity (White 2002).) Our impatient decisionmaker would likewise choose to raise money under contracts which are favourable to creditors in the event of default.

Returning to the model in which decisionmakers and social interests are aligned in the debtor country, a different issue is whether similar statements are true about $C$ : is an increase in the lump-sum negotiation cost, which increases borrowing capacity, a good thing except in the sort of circumstances outlined above? Clearly there is a deadweight loss associated with $C$, whereas $\beta$ only effects a transfer, although it does have a distortionary effect on investment. Certainly increases in $C$ are beneficial in some cases. On the other hand, it is not difficult to find examples where increasing $C$ is bad, but increases in $\beta$ are not. Consider the following parameter values: $r=0 ; \pi_{B}=0.1$; $\pi_{G}=0.9 ; \quad \beta=0.2 ; C=2 ; \omega_{1}=10 ; \theta_{B}=3 ; \theta_{G}=30 ; \gamma=0.2 ; \rho=2$. Here there is a high rate of return on investment, and although consumption in the bad state is low, increases in $\beta$ actually allow $c_{B}$ to increase as $k$ increases with the extra borrowing capacity, and there is a positive effect of $\beta$. However utility is declining in $C$. We can

30 It might seem that one could construct examples where there is a high rate of return on investment but net income in the bad state with default is so low that increasing $\beta$ would be bad. However, in all the simulations either the extra borrowing capacity allows investment to produce sufficient extra output in this state to offset the output extracted by creditors, or a no default contract which avoids incurring the cost $C$ is preferable. 
tentatively conclude that a bankruptcy code that cuts $C$ is likely to be beneficial provided that in cases where extra borrowing capacity is a good thing, bargaining power can be shifted in favour of the creditors to offset the cut in $C$. However in reality the proposals on the table are likely to involve both a cut in $C$ and in $\beta$.

\section{Conclusions}

The paper has presented an overview of the principal issues involved in translating domestic bankruptcy procedures to the sovereign context. While the collective action problems inherent in sovereign insolvency are addressed by proposed bankruptcy procedures, there remain important differences between proposals on the question of whether there should be a radical write down of debt or whether the mechanism should merely aim to restore debt sustainability. Of the two proposals considered in some detail, there remains a considerable vagueness about what happens in the case where agreement cannot be reached by the parties concerned. The paper also considered the question of the ex ante effects (in terms of whether future capital flows to developing countries would be deterred) of a procedure which makes default less costly, and concludes that despite a negative impact on the ability to borrow, the overall welfare effect need not be negative. While it is not possible to derive general results, except in the simplest cases, some broad conclusions emerge. If the sovereign is not very constrained by its capacity to borrow, bankruptcy procedures are likely to improve welfare; likewise if there are distortions which imply that overborrowing is a problem.

\section{References}

Alesina, Alberto, and Guido Tabellini (1989). 'External Debt, Capital Flight and Political Risk,' Journal of International Economics, 27 (3-4): 199-220.

Birdsall, Nancy, and John Williamson (2002). 'Delivering on Debt Relief: From IMF Gold to a New Aid Architecture'. Washington, DC: Institute for International Economics.

Boorman, Jack (2002). 'Sovereign Debt Restructuring: Where Stands the Debate?' Washington, DC: IMF. Available online at: www.imf.org/external/np/speeches/ 2002/101702.htm.

Bulow, Jeremy (2002). 'First World Governments and Third World Debt: A Bankruptcy Court for Sovereign Lending?'. Paper presented at the Brookings Panel, April 4-5. (Forthcoming in Brookings Papers on Economic Activity).

Bulow, Jeremy, and Kenneth Rogoff (1990). 'Cleaning Up Third World Debt without Getting Taken to the Cleaners'. Journal of Economic Perspectives, 4 (1): 31-42.

Diamond, Douglas, and Philip Dybvig (1983). 'Bank Runs, Deposit Insurance, and Liquidity'. Journal of Political Economy, 91: 401-19.

Eaton, Jonathan (1990). 'Debt Relief and The International Enforcement of Loan Contracts'. Journal Of Economic Perspectives, 4: 43-56. 
Eaton, Jonathan (2002). 'Standstills and an International Bankruptcy Court'. New York: New York University. Mimeo.

Eaton, Jonathan, and Mark Gersovitz (1981). 'Debt with Potential Repudiation'. Review of Economic Studies, 48: 289-309.

Eichengreen, Barry (2002). 'Crisis Management: Canvassing the Options'. Paper presented at the conference on Sovereign Debt Workouts: Hopes and Hazards, April 1-2. Washington, DC: Institute for International Economics.

Eichengreen, Barry, and Ashoka Mody (2000). 'Would Collective Action Clauses Raise Borrowing Costs?'. NBER Working Paper 7458. Cambridge, MA: National Bureau of Economic Research.

Eichengreen, Barry, and Richard Portes (1995). 'Crisis? What Crisis? Orderly Workouts for Sovereign Debtors'. London: CEPR.

Group of Ten (1996). 'The Resolution of Sovereign Debt Crises'. The Rey Report to the Ministers and Governors prepared under the auspices of the G-10 Deputies.

Gropp, Reint, John Karl Scholz, and Michelle J. White (1997). 'Personal Bankruptcy and Credit Supply and Demand'. Quarterly Journal of Economics, 112 (1): 217-51.

IMF (2002). 'Sovereign Debt Restructuring Mechanism-Further Considerations'. Washington, DC: IMF. Available at: www.imf.org/External/np/pdr/sdrm/ 2002/081402.pdf.

Kletzer, Kenneth (1984). 'Asymmetries of Information and LDC Borrowing with Sovereign Risk'. Economic Journal, 94: 287-307.

Kremer, Michael, and Seema Jayachandran (2001). 'Odious Debt'. Cambridge, MA: Harvard University. Mimeo.

Krueger, Anne (2001). 'A New Approach to Sovereign Debt Restructuring'. Washington, DC: IMF. Available at: www-personal.umich.edu/ kathrynd/IMF DebtRestructuring.Krueger.pdf

Krueger, Anne (2002). 'A New Approach to Sovereign Debt Restructuring'. Washington, DC: IMF. Available at: www.imf.org/external/pubs/ft/ exrp/sdrm/eng/sdrm.pdf.

Krueger, Anne (2002a). 'New Approaches To Sovereign Debt Restructuring: An Update On Our Thinking'. Paper presented at the conference on Sovereign Debt Workouts: Hopes and Hazards', April 1. Washington, DC: Institute for International Economics. Available at: www.imf.org/external/np/speeches/2002/040102.htm.

Miller, Marcus (2002). 'Sovereign Debt Restructuring: New Articles, New Contracts or No Change?'. International Economics Policy Briefs, No. PB02-3. Washington, DC: Institute for International Economics.

Miller, Marcus, and Lei Zhang (2000). 'Sovereign Liquidity Crises: The Strategic Case for a Payments Standstill'. Economic Journal, 110: 335-62.

Pettifor, Ann (2002). 'Resolving International Debt Crises - the Jubilee Framework for International Insolvency'. NEF Report. London: New Economics Foundation. Available at: www.jubilee2000uk.org/analysis/reports/jubilee_framework.html. 
Raffer, Kunibert (1990). 'Applying Chapter 9 Insolvency to International Debts: An Economically Efficient Solution with a Human Face'. World Development, 18 (2): 301.

Rogoff, Kenneth, and Jeromin Zettelmeyer (2002). 'Early Ideas on Sovereign Bankruptcy Reorganization: A Survey'. IMF Working Paper 02/57. Washington, DC: IMF. Available at: www.imf.org/external/pubs/ft/wp/2002/wp0257.pdf .

Roubini, Nouriel (2002). 'Private Sector Involvement in Crisis Resolution and Mechanisms for Dealing with Sovereign Debt Problems'. New York: Stern School of Business, New York University. Mimeo.

Sachs, Jeffrey D. (1995). 'Do We Need an International Lender of Last Resort?'. Frank D. Graham Lecture at Princeton University, 20 April. Unpublished manuscript. Available at: www.ksg.harvard.edu/cid/ciddirector/publicat.html\#Working.

Sachs, Jeffrey D. (2002). 'Resolving the Debt Crisis of Low-Income Countries,' Paper presented at the Brookings Panel, April 4-5.

Taylor, John (2002). 'Sovereign Debt Restructuring: A US Perspective'. Remarks at conference on Sovereign Debt Workouts: Hopes and Hazards, 1-2 April. Washington, DC: Institute for International Economics. Available at: www.treas.gov/press/releases/po2056.htm .

White, Michelle (2002). 'Sovereigns in Distress: Do They Need Bankruptcy?' Paper presented at the conference on Sovereign Debt Workouts: Hopes and Hazards, 1-2 April 1-2. Washington, DC: Institute for International Economics, and at the Brookings Panel, April 4-5. (Forthcoming in Brookings Papers on Economic Activity). 